\author{
STANISŁAW RAKUSA-SUSZCZEWSKI \\ członek rzeczywisty PAN \\ E-mail: rakusa.suszczewski@gmail.com
}

\title{
KONWENCJA O ZACHOWANIU ŻYWYCH ZASOBÓW MORSKICH ANTARKTYKI (CCAMLR)
}

\section{PRZYCZYNY UTWORZENIA KONWENCJI}

W 1975 r. decyzja Sekretarza Naukowego PAN podjęto się organizacji Pierwszej Polskiej Naukowej Ekspedycji Morskiej do Antarktyki. Powodem była trudna sytuacja naszego rybołówstwa, któremu ograniczono łowiska na północy, w wyniku decyzji politycznych krajów zachodnich wywierajacych coraz większa presję na kraje socjalistyczne. Duża flota naszych trawlerów tracaca te rejony była w sytuacji kryzysowej. Moja propozycje budowy Stacji Antarktycznej, mogacej służyć również pomoca flocie rybackiej, przyjęto pozytywnie. W pierwszym etapie zdecydowano zorganizować wyprawę celem rozpoznania możliwości połowów $\mathrm{w}$ Antarktyce. Byłem kierownikiem naukowym tej wyprawy na statkach: r/v Profesor Siedlecki, należącym do Morskiego Instytutu Rybackiego, i m/t Tazar - trawlera przemysłowego $z$ przedsiębiorstwa „Odra”. W organizację tej wyprawy zaangażował się Wydział II PAN w osobach profesorów: Adama Urbanka, Leszka Kuźnickiego i Romualda Klekowskiego, którym jeszcze raz składam wyrazy wdzięczności.

Zasoby ryb i kryla w Antarktyce w latach 60-70. XX w eksploatowały rabunkowo statki radzieckie. Możliwość przyłączenia się PRL wywołała zaniepokojenie krajów zachodnich. W RFN zorganizowano również dwa statki: naukowy i przemysłowy, które wyruszyły na łowiska Antarktyki w rejon naszych badań i połowów i ...obserwowaliśmy się $z$ uwaga. W naszej wyprawie połowy kryla były priorytetem, co argumentowaliśmy hasłem: kryl jest ważnym dla eko- systemu skorupiakiem stanowiacym pokarm ryb, ptactwa, fok i wielorybów. Łowiliśmy go eksperymentalnie zajmując się technika połowów, technologia przetwórstwa $\mathrm{i}$ badaniami podstawowymi, będacymi domena statku naukowego. Rozpoznano również możliwości połowów ryb, a wyniki były na tyle interesujace, że rok później polska flota statków przemysłowych zeszła w rejon $\mathrm{Za}-$ chodniej Antarktyki. W tym czasie budowaliśmy stacje im. Arctowskiego (RAKUSA-SUSZCZEWSKI 2017, 2019), która dawała prognozy pogody dla floty, parokrotnie udzielano pomocy medycznej rybakom, ratując życie oraz dawano wodę i paliwo w sytuacjach kryzysowych. Poza badaniami podstawowymi stacja służyła flocie rybackiej, co gwarantowało wsparcie dla jej funkcjonowania.

Widzac rabunkowe połowy w Antarktyce, kraje zachodnie $z$ inicjatywy USA zaproponowały międzynarodowy program o kryptonimie BIOMASS (badanie ekosystemu i zasobów), który miał być podstawą naukowa do decyzji o tworzeniu zasad zachowania żywych zasobów Antarktyki. Polska, dzięki posiadaniu nowoczesnego statku badawczego r/v Profesor Siedlecki, włączyła się do tego programu. Poza nami $\mathrm{w}$ programie brały udział statki: RFN, Argentyny, Chile, UK, RPA, Francji, Australii i Japonii. Cztery wyprawy zorganizowane przez PAN, którymi kierowałem, pozwoliły na wykształcenie w Polsce wielu specjalistów oceanobiologów i dały ciekawe wyniki badań podstawowych. Opracowano także wiele patentów. Sprawy zwiazane $z$ rybołówstwem prowadził Morski Instytut Rybacki, współpracując z USA i organizacja National Oceanic and Atmospheric 
Administration (NOAA). Polska od poczatku aktywnie uczestniczyła w formułowaniu Konwencji do spraw Zachowania Żywych Zasobów Morskich Antarktyki (CCAMLR), mając wielu specjalistów badań podstawowych i wiedze o wynikach połowów statków przemysłowych. Byliśmy wtedy liderami, z którymi się liczono. W latach 80. polska flota łowiła na tym obszarze kergulenę, nototenię i kryla, a od połowy lat 90 . prowadziła wyłacznie połowy kryla. W Subantarktyce łowiliśmy kalmary. Od lipca 2011 r. Polska nie poławia na obszarze Konwencji CCAMLR.

\section{ANTARKTYKA I JEJ ZASOBY ŻYWE.}

Rejon Południowego Oceanu stanowi 15\% powierzchni światowego obszaru mórz i rozpościera się od brzegu kontynentu Antarktydy do strefy Konwergencji Antarktycznej (50$\left.60^{\circ} \mathrm{S}\right)$, gdzie zimne wody zagłębiaja się pod cieplejsze subantarktyczne. Obszar obejmuje trzy strefy odmienne ekologicznie: wolna od lodu na północy, sezonowa strefę paku lodowego i obszar trwałej pokrywy lodowej. Eksploatacja zasobów morskich tego rejonu rozpoczęła się w 1790 r., kiedy obiektem połowów były uchatki ze względu na futro, a po ich prawie całkowitej eksterminacji w 1820 r., polowano na słonie morskie i niektóre gatunki pingwinów, celem pozyskania tłuszczu - połowy zakończono w latach 50. XX w. Oddzielna konwencja o ochronie fok zezwala na połowy 175000 krabojadów (jest ich około $35 \mathrm{mln}$.), 12000 lampartów morskich i 5000 fok Weddella; całkowita ochrona objęto rzadkie foki Rossa, słonie morskie i niektóre gatunki uchatek. Połowy wielorybów rozpoczęto w 1904 r. i eksploatowano siedem ich gatunków. Moratorium na połowy wprowadzono w 1987 r. Jedynie Japonia prowadzi połowy coroczne małych wielorybów Minki w ilości kilkuset osobników w celach naukowych i za zgoda konwencji wielorybniczej. Zasoby tych wielorybów, wcześniej nie eksploatowanych, ocenia się w Antarktyce na 460-690 tys. sztuk. Od 1960 r. z różna intensywnościa prowadzone były połowy ryb, krabów, kalmarów i kryla, którym towarzyszyły badania. Polska $\mathrm{w}$ tych badaniach uczestniczyła w latach 70-80. Obecnie, nie posiadajac statku badawczego, jest jedynie obserwatorem. Na ostatniej sesji CCAMLR w 2019 r. zaprezentowano wyniki badań biomasy kryla na Południowym Atlantyku, która oceniono na $62.6 \mathrm{mln}$. ton. Jest to wielkość podobna do $60 \mathrm{mln}$. ton $\mathrm{z}$ oszacowań w 2000 r. W ciagu najbliższych lat zostanie uruchomiony duży program badawczy, który zapewni nowe podejście do zarzadzania połowami kryla. Ma on objać różne obszary Antarktyki i wykorzystać zarówno badania, jak i informacje ze statków rybackich, celem zapewnienia zrównoważonych połowów w przyszłości. Do lat 90. ubiegłego wieku przemysł rybołówczy koncentrował się na krylu, antarze (Dissostichus eleginoides) i rybach białokrwistych, tzn. kergulenach oraz kalmarach i krabach. Szczególnie cennym okazaly się zasoby antara ( $D$. mawsoni). Sposób połowów tych gatunków miał szczególnie niekorzystny wpływ na ptactwo. Stosowano wielokilometrowe liny $z$ hakami i przynęta, która łowiła równieżptaki, głównie albatrosy. Jak donosza oficjalne statystyki, połowy niektórych gatunków, jak np. antara, moga być celowo zaniżane pięć-sześć razy.

Połowy na obszarze objętym Konwencja, prowadzone głównie celem pozyskania obu gatunków Dissostichus, ryb białokrwistych z rodzaju Chamsocephalus i kryla (Euphausia superba), przesunęly się z Oceanu Indyjskiego w rejony Atlantyku, Półwyspu Antarktycznego i Cieśniny Brasfielda, w sasiedztwo stacji im. Arctowskiego. W 1993 r. połowy wynosiły 64000 ton, zaś w 2009 r. osiągnęly 131000 ton. W rejonie Pacyfiku polowy nie sa prowadzone. Ważnymi przemysłowymi gatunkami ryb sa też świetlikowate (Myctophidae) i nototenie ( $N$. rossii i Patagonotothen guntheri), doskonale znane $\mathrm{z}$ głodnego polskiego rynku w latach 80 .

\section{KONWENCJA CCAMLR}

W dniach 7-20 maja 1980 r. w Canberze podpisano Konwencję o Zachowaniu Żywych Zasobów Antarktyki (https://www.ccamlr. org/en/organisation/home-page), stanowiaca odpowiedź na obawy braku regulacji i wzrastajace połowy ryb i kryla w Południowym Oceanie, które moga wpłynąć negatywnie na antarktyczny ekosystem, w tym na warunki pokarmowe ptactwa, fok, wielorybów i ryb, grup zależnych pokarmowo od tego skorupiaka. Konwencja jest związana z Układem Antarktycznym, utworzyła także własny Komitet i Komisję. W organach tych pracowali również Polacy. Wszyscy członkowie Komisji sa również członkami Komitetu Naukowego, który jest ciałem doradczym Komisji, i razem $z$ zespołem ekspertów prowadzacych badania naukowe udziela jej rekomendacji w oparciu o dostępne wyniki badań. Konwencja CCAMLR dotyczy wszystkich antarktycznych populacji ryb, mięczaków, skorupiaków i morskich ptaków występujacych na południe od Antarktycznej Konwergencji. Zasoby fok i wielorybów w Antarktyce reguluja oddzielne Konwencje międzynarodowe. Polska podpisała i ratyfikowała wszystkie.

Obecnie w składzie Komisji CCALMR jest 26 krajów i Unia Europejska. Polskę 
reprezentuje przedstawiciel Ministerstwa Gospodarki Morskiej i Żeglugi Śródlądowej pani Renata Wieczorek. W skład Komitetu Naukowego wchodzi szereg grup roboczych, które spotykaja się w ciagu roku i wspieraja go w formułowaniu opinii naukowych w kluczowych obszarach:

1. grupa zajmujaca się monitorowaniem ekosystemów i ich zarządzaniem (EMM) oraz ocena zasobów kryla i organizmów od niego uzależnionych, opracowuje porady dotyczace zarządzania stanem ekosystemów morskich i przegotowuje doradztwo w zakresie ochrony przestrzennej Morskich Obszarów Chronionych i szczególnie wrażliwych ekosystemów morskich;

2. grupa zajmujacca się oceną zasobów ryb (FSA) szczególnie w obszarze objętym Konwencja. Zapewnia doradztwo w zakresie wpływu rybołówstwa na gatunki niebędace przedmiotem zainteresowania eksploatacyjnego;

3. grupa zajmujaca się statystyka, oszacowywaniem i modelowaniem (SAM) oraz programem znakowania i jego rezultatami. Opracowuje i ocenia metody szacowania nielegalnych połowów oraz ocenia przełowienia gatunków, szczególnie antara;

4. grupa zajmujaca się przypadkowa śmiertelnościa zwiąana $z$ przemysłem połowowym (IMAF) - jej celem jest wypracowanie rekomendacji celem zmniejszenia śmiertelności ptaków morskich w trakcie połowów na obszarze Konwencji;

5. podgrupa zajmujaca się akustycznymi metodami oceny zasobów i ich analizy (ASAM).

Ponadto w Komitecie CCAMLR działa:

- schemat systemu obserwacji międzynarodowych (SISO), (CEMP),

- program monitoringu ekosystemów

- program dotyczacy morskich zanieczyszczeń,

- program kształcenia specjalistów.

Grupa CCALMR, zajmująca się morskimi strefami ochronnymi (MPAs) i obszarami szczególnie wrażliwymi (VMEs), wspiera działania i zarzadza funduszem celem rozwoju i wdrażania stref ochronnych na obszarze Konwencji.

Działalność CCALMR jest finansowana $z$ narodowych środków państw członków tej organizacji. Centrala mieści się w Hobard na Tasmanii. Przedstawiciele państw spotyka- ją się tam raz do roku. Komisja rozpatruje rekomendacje Komitetu Naukowego, a decyzje podejmowane sa na zasadzie konsensusu. Programy naukowe CCALMR, środki na edukację, szczególnie ludzi młodych, oraz własne recenzowane wydawnictwo cztero-języczne CCAMLR Science (w roku 2019 Impact Factor 3.66), stawia tę organizację na wysokim poziomie naukowym. Powinno to znaleźć również swoje odzwierciedlenie w zainteresowaniu środowiska naukowego polskiego Komitetu Badań Polarnych PAN przy Prezydium Polskiej Akademii Nauk. Wielu krajowych specjalistów zajmujacych się Antarktyka, w tym badaniami na stacji im. Arctowskiego podległej IBB PAN, może służyć swoja wiedza (i robili to w latach ubiegłych), szczególnie w programach obszarów objętych ekologicznym monitoringiem i ich zarzadzaniem. Celem jest ochrona tego unikatowego środowiska w skali światowej i racjonalne wykorzystanie jego zasobów przez zainteresowane kraje prowadzace tam połowy.

W przeciwieństwie do Konwencji CCALMR, sytuacja dotyczaca bardzo bogatych zasobów mineralnych w Antarktyce na razie nie jest rozwiazana. W 1998 r. weszło w życie porozumienie członków Układu Antarktycznego o niepodejmowaniu w Antarktyce eksploatacji zasobów mineralnych i obowiazuje ono bezterminowo, co warte jest odnotowania. Badania dotyczace poszukiwania ropy/gazu i innych zasobów, określane jako podstawowe, sa jednak, $z$ pewnymi ograniczeniami, prowadzone.

Artykuł oparto o dane liczbowe $z$ raportu CCAMLR z dnia 21 października 2019.

$$
\text { Streszczenie }
$$

CCALMR powstała w 1980 r. celem stworzenia zasad zachowania, ochrony i racjonalnej eksploatacji żywych zasobów Antarktyki. Polska uczestniczyła od początku prac nad konwencja. Poziom naukowy ekspertów, publikacje i decyzje podejmowane przez Komisje i Komitety Naukowe CCALMR sa bardzo wysokie. Polskie badania na stacji Arctowskiego były wielokrotnie prezentowane na posiedzeniach Grup Roboczych tej konwencji.

\section{LITERATURA}

RAKUSA-SusZcZEWSKI S., 2017. Założenie polskiej stacji antarktycznej im. Henryka Arctowskiego (1976/1977) - dziennik prof. Stanisława Rakusa-Suszczewkiego. Kosmos 66, 503-508.

RAKUSA-SUSZCZEWSKI S., 2019. Polska w Antarktyce. Nauka 2, 183-187. 
KOSMOS Vol. 69, 2, 381-384, 2020

\section{STANISEAW RAKUSA-SUSZCZEWSKI}

E-mail: rakusa.suszczewski@gmail.com

\section{CCAMLR}

\section{Summary}

The CCALMR Convention was established in 1980 for conservation, protection and rationally exploiting Antarctic living resources. Poland has participated in its creation from the beginning. The scientific level of experts, publications and decisions taken by the Commission and the Scientific Committee is very high. Polish research at Arctowski station on South Shetlands Islands was presented in Working Group of Commission.

Key words: Antarctic, CCAMLR 